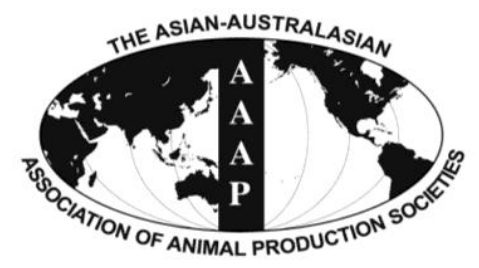

Asian-Aust. J. Anim. Sci.

Vol. 25, No. $3: 311$ - 319

March 2012

www.ajas.info

http://dx.doi.org/10.5713/ajas.2010.10014

\title{
Effect of Supplementation of Fish and Canola Oil in the Diet on Milk Fatty Acid Composition in Early Lactating Holstein Cows
}

\author{
Toktam S. Vafa ${ }^{1 * *}$, Abbas A. Naserian ${ }^{2}$, Ali R. Heravi Moussavi ${ }^{2}$, \\ Reza Valizadeh $^{2}$ and Mohsen Danesh Mesgaran ${ }^{2}$ \\ ${ }^{1}$ Payame Noor University, EX phD student at Ferdowsi University of Mashhad, Mashhad, Iran \\ ${ }^{2}$ Excellence Center for Animal Science, Faculty of Agriculture, Ferdowsi University of Mashhad, \\ P. O. Box 91775-1163. Mashhad, Iran
}

\begin{abstract}
This study examined the effects of supplementation of fish oil and canola oil in the diet on milk yield, milk components and fatty acid composition of Holstein dairy cows in early lactation. Eight multiparous early lactation Holstein cows (42 \pm 12 DIM, $40 \pm 6 \mathrm{~kg}$ daily milk yield) were fed a total mixed ration supplemented with either $0 \%$ oil (Control), $2 \%$ fish oil (FO), $1 \%$ canola oil $+1 \%$ fish oil (FOCO), or $2 \%$ canola oil (CO) according to a double $4 \times 4$ Latin square design. Each period lasted 3 wk; experimental analyses were restricted to the last week of each period. Supplemental oils were added to a basal diet which was formulated according to NRC (2001) and consisted of $20 \%$ alfalfa, $20 \%$ corn silage and $60 \%$ concentrate. Milk yield was similar between diets ( $p>0.05$ ), but dry matter intake (DMI) was lower $(\mathrm{p}<0.05)$ in cows fed FO diet compared to other diets. Milk fat percentage and daily yield decreased $(\mathrm{p}<0.01)$ with the supplementation of fish and canola oil. The daily yield and percentage of milk protein, lactose and solids-not-fat (SNF) were not affected by diets ( $\mathrm{p}>0.05)$. The proportion ( $\mathrm{g} / 100 \mathrm{~g}$ fatty acids) of short chain fatty acids (SCFA) decreased and polyunsaturated fatty acids (PUFA) increased $(\mathrm{p}<0.05)$ in milk of all cows fed diets supplemented with oil. The proportions of 6:0, 8:0, 10:0 12:0 and 14:0 fatty acids in milk fat decreased $(\mathrm{p}<0.01)$ for all diets supplemented with oil, but the proportions of 14:1, 16:0 and 16:1 fatty acids were not affected by diets $(\mathrm{p}>0.05)$. The proportion of trans $(t)-18: 1$ increased $(\mathrm{p}<0.01)$ in milk fat of cows fed FO and FOCO diets, but CO diet had the highest proportion of $c i s(c)-11$ 18:1 ( $\mathrm{p}<0.01)$. The concentration of $t-10, c-12$ 18:2, $c-9 t-11$ 18:2, 18:3, eicosapentaenoic acid (EPA, 20:5) and docosahexaenoic acid (DHA, 22:6) increased ( $\mathrm{p}<0.05)$ in FO and FOCO diets in comparison with the other two diets. These data indicate that including fish oil in combination with canola oil significantly modifies the fatty acid composition of milk. (Key Words : Fish Oil, Canola Oil, Milk Fatty Acid Composition, Holstein Dairy Cows)
\end{abstract}

\section{INTRODUCTION}

Due to increased demand for value-added foods with health benefits, strategies have been initiated to produce dairy products enriched with conjugated linoleic acid (Ip et al., 1999). Conjugated linoleic acid (CLA) refers to a group of positional and geometrical isomers of linoleic acid $(c 9$, $c 12$ octadecadienoic acid) with conjugated double bonds. Two CLA isomers, $c 9, t 11$ and $t 10, c 12$, have been reported as the most biologically active isomers (Bauman et al., 2001). Much recent research has focused on increasing the amount of $c 9, t 11-18: 2$ and $t 11-18: 1$ (vaccenic acid) in milk fat and products because of reported health benefits such as

\footnotetext{
*Corresponding Author : Toktam Sadat vafa. Tel : +98-91552 13325, Fax : +98-5118796845, E-mail : vafa_toktam@yahoo.com Submitted Jan. 9, 2010; Accepted Mar. 19, 2010; Revised May 17, 2010
}

protection against certain cancers, diabetes, immunity, atherosclerosis, bone growth and obesity (Parodi, 1997; Ip et al., 2003). Vaccenic acid is produced in rumen bacteria by the action of their isomerases and reductases from dietary PUFA, and is subsequently converted to $c 9, t 11-18: 2$ by $\Delta^{9}$-desaturase in the tissues of ruminants (Griinari et al., 2000). Supplementing the diet of cows with long chain unsaturated lipid decreased the medium chain fatty acids $(10: 0,12: 0$, and 14:0) and increased the 18:0 and 18:1 in milk fat (DePeters et al., 2001; AbuGhazaleh et al., 2002; Ward et al., 2002).

Fish oil which contains relatively high concentrations of two PUFA of the n-3 family, EPA and DHA, is an effective means of increasing CLA in milk fat, due to an inhibition of $t-18: 1$ reduction in the rumen that results in an increased supply of t-11 18:1 which would be available for 
endogenous conversion to $c 9, t 11-18: 2$ (CLA) in the mammary gland (Shingfield et al., 2003). Including FO in dairy diets also increased the content of EPA and DHA in milk, even though the transfer efficiencies of DHA $(3 \%)$ and EPA (4\%) into milk fat are very low (Chilliard et al., 2001). It has been shown that DHA has an inhibitory effect on reduction of $t 11-18: 1$ to $18: 0$ which results in a higher proportion of $t 11-18: 1$ in rumen bacteria (Lee et al., 2005).

The combination of marine lipids and 18:2 rich plant oils is an established strategy to modify ruminal biohydrogenation for increasing CLA in milk fat (Palmquist and Griinari, 2006). Canola seed, containing only about $6 \%$ 16:0 and up to $58 \% c-18: 1$ and with a much higher $c-18: 1$ to $16: 0$ ratio than other common oilseeds, has potentially interesting characteristics to change the fatty acid profile of milk fat (Bayourthe et al., 2000). Our objective was to evaluate the effects of feeding fish oil and canola oil separately and in combination on milk yield, milk components and milk fatty acid profile in early lactating Holsteins.

\section{MATERIALS AND METHODS}

\section{Animals and diets}

Eight multiparous Holstein cows in early lactation (42 \pm 12 DIM, $40 \pm 6 \mathrm{~kg} / \mathrm{d}$ milk yield) were assigned to one of four dietary treatments according to a replicated $4 \times 4$ Latin square with four treatments, four periods, and two cows per treatment. Each period lasted $21 \mathrm{~d}$, which included a 14-d diet adjustment period followed by a sampling period. There were four treatments consisting of diet with no supplemental oil (Control), and a basal diet supplemented with fish oil and canola oil at different levels which included $2 \%$ fish oil (FO), $1 \%$ fish oil-1\% canola oil (FOCO), and $2 \%$ canola oil (CO). Net energy content of diets was calculated from the ingredient composition. Diets were composed of $60 \%$ (DM) concentrate mix, $20 \%$ alfalfa hay, and $20 \%$ corn silage and formulated to meet energy and protein requirements (NRC, 2001) of lactating cows producing $40 \mathrm{~kg}$ of milk and consuming $25 \mathrm{~kg}$ of DM/d (Table 1). Oils were added at a level of about $2 \%$ of dietary $\mathrm{DM}$, resulting in a dietary ether extract content of $4.7 \%$.

Table 1. Ingredients and chemical composition of dairy diets

\begin{tabular}{|c|c|c|c|c|}
\hline \multirow{2}{*}{ Variable } & \multicolumn{4}{|c|}{ Treatments $^{1}$} \\
\hline & Control & $\mathrm{FO}$ & FOCO & $\mathrm{CO}$ \\
\hline \multicolumn{5}{|l|}{ Ingredients (\% of DM) } \\
\hline Alfalfa & 20 & 20 & 20 & 20 \\
\hline Corn silage & 20 & 20 & 20 & 20 \\
\hline Corn grain & 15 & 13 & 13 & 13 \\
\hline Barely grain & 15 & 15 & 15 & 15 \\
\hline Soybean meal & 10 & 10 & 10 & 10 \\
\hline Canola meal & 8 & 8 & 8 & 8 \\
\hline Bran & 10.5 & 10.5 & 10.5 & 10.5 \\
\hline Fish oil $^{2}$ & - & 2 & 1 & - \\
\hline Canola oil $^{3}$ & - & - & 1 & 2 \\
\hline Limestone & 0.5 & 0.5 & 0.5 & 0.5 \\
\hline Vitamin supplement & 0.8 & 0.8 & 0.8 & 0.8 \\
\hline Salt & 0.2 & 0.2 & 0.2 & 0.2 \\
\hline \multicolumn{5}{|c|}{ Chemical composition (\% of DM) } \\
\hline $\mathrm{CP}$ & 16.7 & 16.3 & 16.2 & 16.4 \\
\hline $\mathrm{NDF}$ & 32.08 & 33.21 & 32.77 & 33.12 \\
\hline $\mathrm{ADF}$ & 19.07 & 19.02 & 18.87 & 18.66 \\
\hline $\mathrm{OM}$ & 93.06 & 92.48 & 92.63 & 92.48 \\
\hline $\mathrm{NFC}^{4}$ & 41.40 & 38.31 & 39.16 & 38.39 \\
\hline Ether extract & 2.78 & 4.62 & 4.67 & 4.53 \\
\hline $\mathrm{Ca}$ & 0.8 & 0.8 & 0.8 & 0.8 \\
\hline $\mathrm{P}$ & 0.6 & 0.6 & 0.6 & 0.6 \\
\hline $\mathrm{Mg}$ & 0.27 & 0.27 & 0.27 & 0.27 \\
\hline $\mathrm{NE}_{\mathrm{L}}(\mathrm{Mcal} / \mathrm{kg})$ & 1.53 & 1.60 & 1.61 & 1.59 \\
\hline
\end{tabular}


Kilika fish oil (khazar Co, Babolsar, Iran), and canola oil (Golestan Soybean Co, Gorgan, Iran) were used in this experiment. The oils were added first to part of the bran and soybean meal to produce a premix, then, after mixing well, were added to the other part of the concentrate weekly. Concentrate mixtures and forage sources were mixed in a weighing and mixing unit and offered in TMR form twice daily to allow $5-10 \%$ orts (as-fed basis). Cows were housed in free stalls with continuous access to water and were milked daily at 0500, 1200, and 2000.

\section{Sampling, measurement, and analysis}

TMR mixtures were sampled daily during the sampling period and were stored in $-20^{\circ} \mathrm{C}$. At the end of each period, feed samples were pooled to obtain representative samples for final analysis which were stored at $-20^{\circ} \mathrm{C}$ until the end of the experiment. Finally, all the feed samples were dried in a forced-air oven at $60^{\circ} \mathrm{C}$, and stored in sealed plastic containers at room temperature until analyzed. Dried feed samples were ground through a 2-mm screen (Wiley; Arthur H. Thomas, Philadelphia, PA) and were analyzed for fat, ADF, NDF by wet chemistry procedures (Table 1) and for fatty acid composition using gas liquid chromatography (Table 2) (provide reference). Dry matter intake (DMI) and milk yield were recorded daily, but only data obtained on the sampling days of each experimental period were used for statistical analysis. Duplicate subsamples of milk were collected at the regular milking time over a 48 -h period (six consecutive milkings) for two consecutive days of each period. One sample was stored at $4^{\circ} \mathrm{C}$ until analyzed for fat, protein and SNF (Micro Scan; FOSS Electric A/s, Denmark). The second sample was stored at $-20^{\circ} \mathrm{C}$ until analysis for fatty acid composition using gas liquid chromatography.

\section{Fatty acid analysis of milk}

Total milk lipid was extracted using hexane:isopropanol (3:2 vol/vol) mixture at a 7:4 solvent:ration sample volume (Mire et al., 1999). Total fatty acid methyl esters (FAME) of milk lipids were prepared using methanolic sodium and analyzed by gas chromatography (GC Younglin Acme 6000 column bpx70 100*0.25*250 micron SGE company) equipped with a flame ionization detector and silica capillary column $(30 \mathrm{~m} \times 0.32$ (internal diameter) with 0.25 $\mu \mathrm{m}$ film thickness) with hydrogen as the carrier gas. Injector and detector temperatures were maintained at $235^{\circ} \mathrm{C}$ and $250^{\circ} \mathrm{C}$, respectively. The temperature program was as follows: initial temperature of $75^{\circ} \mathrm{C}$ held for $1 \mathrm{~min}$, increased by $8^{\circ} \mathrm{C} / \mathrm{min}$ to $165^{\circ} \mathrm{C}$ and held for $35 \mathrm{~min}$, increased by $5.5^{\circ} \mathrm{C} / \mathrm{min}$ to $210^{\circ} \mathrm{C}$, then increased by $15^{\circ} \mathrm{C} / \mathrm{min}$ to $240^{\circ} \mathrm{C}$. The split ratio was $10: 1$ and total fatty acid esters in a $1 \mu \mathrm{l}$ sample were determined. All milk fatty acid results were expressed as $\mathrm{g} / 100 \mathrm{~g}$ of total fatty acids.

\section{Statistical analyses}

Data were analyzed as a replicated $4 \times 4$ Latin square

Table 2. Fatty acid composition (g/100 g of fatty acids) in dairy diets

\begin{tabular}{|c|c|c|c|c|c|}
\hline \multirow{2}{*}{ Fatty acids } & \multicolumn{4}{|c|}{ Treatments $^{1}$} & \multirow{2}{*}{ SEM } \\
\hline & Control & FO & FOCO & $\mathrm{CO}$ & \\
\hline $12: 0$ & 0.22 & 0.12 & 0.11 & 0.11 & 0.02 \\
\hline $14: 0$ & 0.43 & 1.4 & 0.85 & 0.38 & 0.07 \\
\hline $14: 1$ & - & 0.16 & 0.07 & 0.01 & 0.00 \\
\hline $16: 0$ & 16.11 & 13.58 & 12.87 & 11.35 & 0.17 \\
\hline $16: 1$ & 0.19 & 0.2 & 0.1 & 0.07 & 0.01 \\
\hline $18: 0$ & 3.02 & 3.73 & 3.35 & 3.29 & 0.09 \\
\hline $18: 1$ trans & 0.05 & 0.04 & 0.06 & 0.04 & 0.00 \\
\hline $18: 1$ cis-9 & 23.17 & 23.62 & 30.17 & 34.89 & 1.92 \\
\hline 18:1 cis-11 & 2.57 & 2.36 & 2.72 & 2.97 & 0.09 \\
\hline $18: 2$ trans -9, trans -12 & 0.06 & 0.02 & 0.06 & 0.05 & 0.01 \\
\hline $18: 2$ cis -9, cis -12 & 32.7 & 22.5 & 24.03 & 26.56 & 2.4 \\
\hline $18: 2$ trans -10, cis- 12 & ND & ND & 0.04 & 0.07 & 0.00 \\
\hline $18: 2$ trans -9, trans -11 & ND & ND & 0.06 & 0.01 & 0.00 \\
\hline $18: 3$ & 6.11 & 5.95 & 7.14 & 6.65 & 0.6 \\
\hline 20:0 & 0.6 & 0.7 & 0.78 & 0.6 & 0.03 \\
\hline $20: 4$ & 1.86 & 3.12 & 3.73 & 3.17 & 0.38 \\
\hline 20:5 EPA & 0.08 & 2.78 & 1.57 & 0.14 & 0.67 \\
\hline $22: 5$ & 1.3 & 1.11 & 1.09 & 1.92 & 0.15 \\
\hline 22:6 DHA & 0.05 & 3.09 & 1.12 & 0.12 & 0.42 \\
\hline
\end{tabular}

${ }^{1}$ Control = Diet without oil; FO = Diet supplemented with fish oil (2\% DM); FOCO = Diet supplemented with 1\% (DM) fish oil and 1\% (DM) canola oil; and $\mathrm{CO}=$ Diet supplemented with $2 \%(\mathrm{DM})$ canola oil. 
using the generalized linear model (PROC GLM, Inst, Inc) of SAS (1996) with the following model: $Y_{i j k}=$ $\mu+T_{i}+P_{j}+A_{k}+\varepsilon_{i j k}$, where $Y_{i j k}$ is the dependent variable, $\mu$ is the global mean, $T$ is the treatment effect, $P$ is the period effect, $A$ is the animal effect, and $\varepsilon_{i j k}$ is the residual error. Model effects were considered significant at $\mathrm{p}<0.05$.

\section{RESULTS}

Results of supplementing diets with fish oil and canola oil on DMI, milk yield and components are presented in Table 3. DMI decreased on FO diet $(\mathrm{p}<0.05)$, but milk yield was not affected by supplemented diets $(p>0.05)$. Fat corrected milk (4\% FCM) and energy corrected milk $(\mathrm{ECM})$ decreased $(\mathrm{p}<0.01)$ on oil supplemented diets. Milk fat percentage and yield decreased $(\mathrm{p}<0.05)$ on FO diet. Supplementing diets with fish oil and canola oil had no effect on milk protein, solids-not-fat (SNF) and lactose percentages and yields ( $\mathrm{p}>0.05)$.

Fatty acid composition of milk fat was altered with fish oil and canola oil supplementation in diets of lactating Holsteins (Table 4). Short and medium chain fatty acids decreased $(p<0.05)$ on all supplemented diets but long chain fatty acids were similar ( $p>0.05$ ) between diets (Figure 1). In comparison with the control diet, the proportion of saturated fatty acids decreased on all supplemented diets with the lowest proportion on FO diet $(\mathrm{p}<0.05)$ and polyunsaturated fatty acids also increased $(\mathrm{p}<0.05)$ on supplemented diets (Figure 2). FO diet produced the lowest proportion of 6:0, 8:0 and 10:0 of all supplemented diets $(\mathrm{p}<0.01)$. The proportion of 12:0 and 14:0 decreased on all supplemented diets $(\mathrm{p}<0.01)$, with the lowest concentration of 14:0 on FOCO diet. However, the proportion of 14:1, 16:0 and 16:1 was not affected by experimental diets $(\mathrm{p}>0.05)$. The proportion of $t-18: 1$ was increased for FO diet $(\mathrm{p}<0.05)$ and FOCO and CO diets produced a higher proportion of $c 11-18: 1 \quad(\mathrm{p}<0.01)$. Concentrations of $t 10$, $c 12-18: 2$ and $c 9, t 11-18: 2(\mathrm{p}<0.05)$ increased on FO and FOCO diets with the higher amount of $c 9$, t11-18:2 on FOCO, but there were no significant differences in $t 9, t 11$ 18:2 and $c 9, c 12-18: 2$ between treatments $(\mathrm{p}>0.05)$. Milk fat of cows fed FO and FOCO diets had higher levels of 18:3, EPA and DHA in comparison with control and CO diets $(p<0.01)$. The proportion of $20: 4$ and $22: 0$ was similar between diet $(p>0.05)$.

\section{DISCUSSION}

Lower DMI is a typical response to fish oil supplementation, especially when the levels of fish oil increase in the diet (Whitlock et al., 2002; Palmquist and Griinari, 2006). The potential negative effect of feeding free oil on food palatability and ruminal fiber digestion occurs because of direct contact between lipids and rumen microorganisms which results in lower DMI (Bayourthe et al., 2000). Abomasal infusion of unsaturated fat, relative to no fat and saturated fat infusions (Benson and Reynolds, 2001), and increasing unsaturated fat supplements linearly

Table 3. Milk yield and composition in early lactating Holsteins fed diets containing fish and canola oil

\begin{tabular}{|c|c|c|c|c|c|c|}
\hline \multirow{2}{*}{ Parameter } & \multicolumn{4}{|c|}{ Treatments $^{1}$} & \multirow{2}{*}{ SEM } & \multirow{2}{*}{$\mathrm{p}$} \\
\hline & Control & FO & FOCO & $\mathrm{CO}$ & & \\
\hline$\overline{\mathrm{DM}}$ & $24.92^{\mathrm{a}}$ & $22.21^{\mathrm{b}}$ & $24.61^{\mathrm{a}}$ & $24.86^{\mathrm{a}}$ & 0.61 & $*$ \\
\hline $\operatorname{Milk}(\mathrm{kg} / \mathrm{d})$ & 34.55 & 33.84 & 34.08 & 33.90 & 0.86 & ns \\
\hline $\mathrm{FCM}^{2} 4 \%(\mathrm{~kg} / \mathrm{d})$ & $31.24^{\mathrm{a}}$ & $23.63^{\mathrm{b}}$ & $27.03^{\mathrm{b}}$ & $27.06^{\mathrm{b}}$ & 1.16 & $* *$ \\
\hline $\operatorname{ECM}^{3}(\mathrm{~kg} / \mathrm{d})$ & $33.34^{\mathrm{a}}$ & $26.81^{\mathrm{b}}$ & $29.96^{\mathrm{b}}$ & $29.69^{b}$ & 1.01 & $* *$ \\
\hline \multicolumn{7}{|l|}{ Fat } \\
\hline$\%$ & $3.43^{\mathrm{a}}$ & $2.32^{\mathrm{b}}$ & $2.47^{\mathrm{b}}$ & $2.67^{\mathrm{b}}$ & 0.13 & $* *$ \\
\hline $\mathrm{kg} / \mathrm{d}$ & $1.17^{\mathrm{a}}$ & $0.68^{\mathrm{b}}$ & $0.87^{\mathrm{b}}$ & $0.90^{\mathrm{b}}$ & 0.05 & $* *$ \\
\hline \multicolumn{7}{|l|}{ Protein } \\
\hline$\%$ & 2.99 & 2.92 & 2.89 & 2.86 & 0.17 & ns \\
\hline $\mathrm{kg} / \mathrm{d}$ & 0.98 & 0.96 & 1.00 & 0.97 & 0.02 & $\mathrm{~ns}$ \\
\hline \multicolumn{7}{|l|}{ Lactose } \\
\hline$\%$ & 4.38 & 4.39 & 4.33 & 4.27 & 0.05 & $\mathrm{~ns}$ \\
\hline $\mathrm{kg} / \mathrm{d}$ & 1.49 & 1.47 & 1.49 & 1.44 & 0.03 & ns \\
\hline \multicolumn{7}{|l|}{ SNF } \\
\hline$\%$ & 7.98 & 8.01 & 7.92 & 7.83 & 0.10 & ns \\
\hline $\mathrm{kg} / \mathrm{d}$ & 2.70 & 2.68 & 2.73 & 2.65 & 0.05 & ns \\
\hline
\end{tabular}

${ }^{1}$ Control = Diet without oil; FO = Diet supplemented with fish oil (2\% DM); FOCO = Diet supplemented with 1\% (DM) fish oil and $1 \%$ (DM) canola oil; and $\mathrm{CO}=$ Diet supplemented with $2 \%(\mathrm{DM})$ canola oil.

${ }^{2} 4 \% \mathrm{FCM}=0.4 \times($ milk yield $(\mathrm{kg}))+15 \times($ fat yield $(\mathrm{kg})) .{ }^{3}$ Energy-corrected milk $=(7.2 \times$ protein yield $(\mathrm{kg})+12.95 \times$ fat yield $(\mathrm{kg})+0.327 \times$ milk yield $(\mathrm{kg}))$. ns $=$ Not significant. $* \mathrm{p}<0.05, * * \mathrm{p}<0.01$. 
Table 4. Milk fatty acid content (g/100 g fatty acid) of dairy cows fed diets containing fish and canola oil

\begin{tabular}{|c|c|c|c|c|c|c|}
\hline \multirow{2}{*}{ Fatty acids } & \multicolumn{4}{|c|}{ Treatments $^{1}$} & \multirow{2}{*}{ SE } & \multirow{2}{*}{$\mathrm{p}$ value } \\
\hline & Control & FO & FOCO & $\mathrm{CO}$ & & \\
\hline$\overline{4: 0}$ & 2.48 & 2.25 & 2.03 & 2.31 & 0.12 & $\mathrm{~ns}$ \\
\hline $6: 0$ & $1.97^{\mathrm{a}}$ & $1.53^{\mathrm{b}}$ & $1.62^{\mathrm{b}}$ & $1.56^{\mathrm{b}}$ & 0.03 & $* *$ \\
\hline $8: 0$ & $1.90^{\mathrm{a}}$ & $1.66^{\mathrm{b}}$ & $1.75^{\mathrm{ab}}$ & $1.58^{\mathrm{b}}$ & 0.02 & $* *$ \\
\hline 10:0 & $2.35^{\mathrm{a}}$ & $1.61^{\mathrm{b}}$ & $1.70^{\mathrm{ab}}$ & $1.87^{\mathrm{ab}}$ & 0.01 & $* *$ \\
\hline $12: 0$ & $2.5^{\mathrm{a}}$ & $2.12^{\mathrm{b}}$ & $2.16^{\mathrm{b}}$ & $2.11^{\mathrm{b}}$ & 0.11 & $* *$ \\
\hline $14: 0$ & $9.20^{\mathrm{a}}$ & $7.55^{\mathrm{c}}$ & $6.86^{\mathrm{bc}}$ & $7.96^{\mathrm{ac}}$ & 0.11 & $* *$ \\
\hline $14: 1$ & 0.27 & 0.2 & 0.21 & 0.2 & 0.02 & $\mathrm{~ns}$ \\
\hline $16: 0$ & 23.16 & 21.24 & 19.05 & 20.65 & 0.76 & ns \\
\hline $16: 1$ & 0.69 & 0.53 & 0.54 & 0.57 & 0.04 & $\mathrm{~ns}$ \\
\hline 18:0 & 13.37 & 12.08 & 11.9 & 12.07 & 1.64 & ns \\
\hline$t-18: 1$ & $0.38^{\mathrm{a}}$ & $1.16^{\mathrm{b}}$ & $0.57^{\mathrm{a}}$ & $0.66^{\mathrm{a}}$ & 0.05 & $* *$ \\
\hline$c 9-18: 1$ & 22.2 & 23.53 & 22.75 & 25.53 & 1.06 & $\mathrm{~ns}$ \\
\hline c11-18:1 & $0.78^{\mathrm{a}}$ & $0.84^{\mathrm{a}}$ & $1.81^{\mathrm{b}}$ & $1.12^{\mathrm{b}}$ & 0.08 & $* *$ \\
\hline$t 9, t 12-18: 2$ & 0.25 & 0.27 & 0.29 & 0.26 & 0.04 & $\mathrm{~ns}$ \\
\hline$c 9, c 12-18: 2$ & 2.56 & 2.74 & 2.98 & 2.84 & 0.06 & ns \\
\hline$t 10, c 12-18: 2$ & $0.05^{\mathrm{a}}$ & $0.13^{\mathrm{b}}$ & $0.15^{\mathrm{b}}$ & $0.06^{\mathrm{a}}$ & 0.02 & $*$ \\
\hline$c 9, t 11-18: 2$ & $0.47^{\mathrm{a}}$ & $1.05^{\mathrm{b}}$ & $1.16^{\mathrm{b}}$ & $0.88^{\mathrm{ab}}$ & 0.09 & $*$ \\
\hline $18: 3$ & $0.44^{\mathrm{a}}$ & $0.69^{\mathrm{b}}$ & $0.60^{\mathrm{b}}$ & $0.48^{\mathrm{a}}$ & 0.01 & $* *$ \\
\hline $22: 0$ & 0.08 & 0.10 & 0.20 & 0.11 & 0.02 & $\mathrm{~ns}$ \\
\hline $20: 4$ & 0.01 & 0.03 & 0.01 & 0.04 & 0.01 & ns \\
\hline 20:5 EPA & $0.05^{\mathrm{a}}$ & $0.26^{\mathrm{b}}$ & $0.17^{\mathrm{b}}$ & $0.04^{\mathrm{a}}$ & 0.001 & $*$ \\
\hline 22:6 DHA & $0.04^{\mathrm{a}}$ & $0.28^{\mathrm{b}}$ & $0.14^{\mathrm{b}}$ & $0.06^{\mathrm{a}}$ & 0.01 & $*$ \\
\hline
\end{tabular}

${ }^{1}$ Control $=$ Diet without oil; FO = Diet supplemented with fish oil (2\% DM); FOCO = Diet supplemented with 1\% (DM) fish oil and 1\% (DM) canola oil; and $\mathrm{CO}=$ Diet supplemented with $2 \%$ (DM) canola oil.

ns $=$ Not significant. $* \mathrm{p}<0.05, * * \mathrm{p}<0.01$

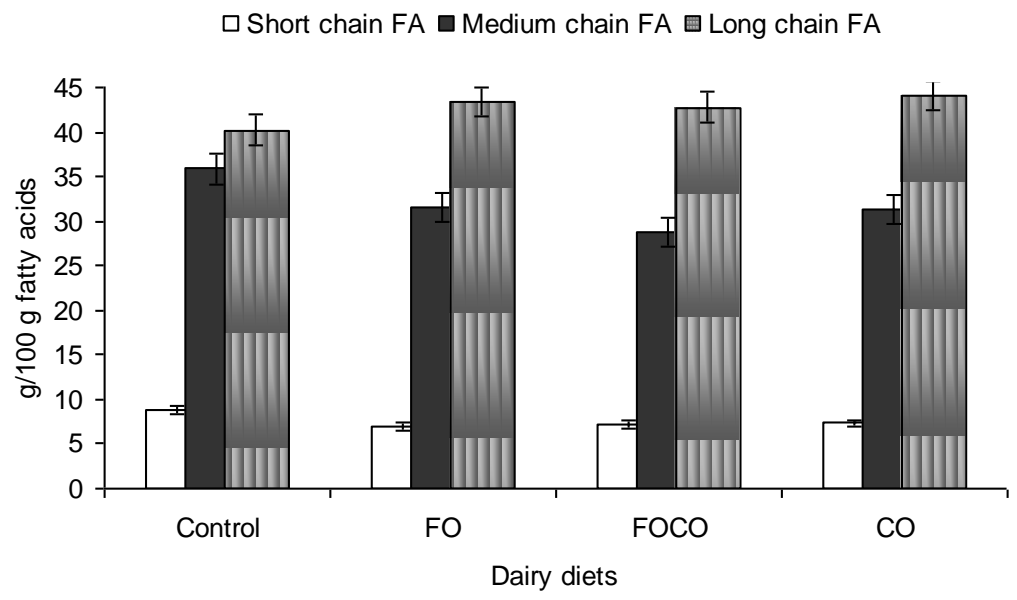

Figure 1. Proportion of short, medium and long chain fatty acids in milk fat of dairy cows fed diets containing fish (FO) and canola oil (CO). Short chain FA: C4:0-C10:0, Medium chain FA: C10:0-C16:0, Long chain FA: >C16:0. 


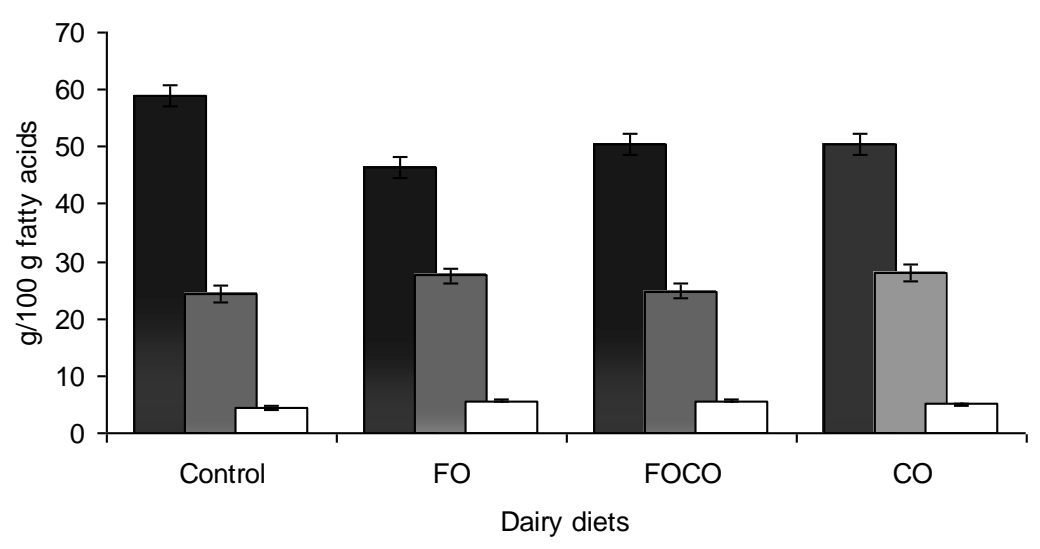

Figure 2. Proportion of saturated, mono and poly unsaturated fatty acids in dairy cows fed diets containing fish (FO) and canola oil (CO).

decreased DMI (Harvatine and Allen, 2006). In the current experiment, DMI was decreased just on FO diet, which was probably because of its lower palatability. However, different form of canola oil in the diet (Jenkins et al., 1998; Bayourthe et al., 2000) and ground canola seed (Ward et al., 2002; Chichlowski et al., 2005) had no significant effects on DMI. Milk yield did not differ between diets. Donovan et al. (2000) reported no significant decline in milk yield until cows were consuming 3\% (DM basis) FO, whereas, in the study of Whitloch et al. (2002) milk yield appeared to be numerically lower in cows consuming a $2 \%$ FO diet. Supplementing diets with oils rich in PUFA often results in a reduction in nutrient intake and milk yield (Chilliard et al., 2001; Lock and Shingfield, 2004). However, there are several previous reports which have reported no significant effects of supplemented oil on milk yield (AbuGhazaleh et al., 2003; Shingfield et al., 2005; Juchem et al., 2008) or an increased milk yield (AbuGhazaleh et al., 2004).

Milk fat percentage and yield were decreased in all oil supplemented diets $\quad(\mathrm{p}<0.01)$. Other researchers (Ramaswamy et al., 2001; AbuGhazaleh et al., 2004) also reported depression in milk fat percentage when oil was incorporated in the diets of cows. Rapid availability of the oil in the diet and its potential effect on fiber digestibility (AbuGhazaleh et al., 2004), incomplete biohydrogenation and yield of various substrates and conjugated linoleic acid isomers, especially $t 10, c 12-18: 2$ (Peterson et al., 2002), which inhibit de novo synthesis of some fatty acids in the mammary gland, are other possible reasons for milk fat decrement when oil is included in diets (Bauman et al., 2003). The results for fatty acid composition of milk fat (Table 4), showed that concentration of $t 10, c 12-18: 2$ increased significantly on FO and FOCO diets, which is another possible reason for milk fat depression on these diets. Milk protein, lactose and SNF concentration and yield were not affected by oil supplementation in the current experiment. Milk protein percentage often decreases when supplemental fat is fed to lactating dairy cows (Chichlowski et al., 2005; Juchem et al., 2008). However, in the study of Jenkins et al. (1998), supplementing the diet with canola oil significantly increased milk protein concentration.

Supplementing dairy diets with C18-unsaturated lipid decreased short and medium chain fatty acids and increased the 18:0 and 18:1 contents of milk fat (DePeters et al., 2001; AbuGhazaleh et al., 2002; Harvantine et al., 2009), with the greatest increase observed when a high linoleic acid source was fed (Kelly et al., 1998; AbuGhazaleh et al., 2003a). Short chain fatty acids are mainly synthesized in the epithelial cells of the mammary gland of dairy cows, and their synthesis is susceptible to inhibition when the levels of certain long chain fatty acids is increased in milk fat (Chichlowski et al., 2005).

Most of the long chain fatty acid (>16:0) increased with supplemental oil in diets (Table 4), but there were no significant effects of diets on total (saturated and unsaturated fatty acids with more than 16 carbons) long chain fatty acids (Figure 1). Oleic acid (18:1) in milk fat is, in part, a consequence of stearoyl-coenzyme-A desaturase activity in the intestinal epithelium and mammary tissue (Depeters et al., 2001). Transfer efficiency of 18:1 from the diet to milk of $9 \%$ was reported for cows fed a diet supplemented with canola oil (Jenkins, 1998), so concentrations of 18:1 in blood and milk are mostly dependent on the rates of conversion of $18: 0$ to $18: 1$ by tissue desaturases (Chang et al., 1992). However, it has been suggested that dietary fat that is rich in $\mathrm{C} 18$ - fatty acids would increase the $18: 1$ content of milk by 50 to $80 \%$ (Grummer, 1991). The FO diet had the highest proportion of milk $t$-18:1 and milk $c 11-18$ :1increased on FOCO and $\mathrm{CO}$ diets. Combining fish oil with extruded soybean 
increased $t 9-18: 1$ and $c 9-18: 1$ (Abughazaleh et al., 2004) and a higher proportion of $t 18: 1$ in milk fat has been reported, based on higher ruminal accumulations of $t-18: 1$ intermediates, when fish oil is fed compared to plant oil, (Chilliard and Ferlay, 2004). Milk fat on all diets had a similar proportion of $c 9-18: 1(\mathrm{p}=0.22)$ which could serve as a precursor for several $t$-fatty acid isomers including $t 11$ 18:1. The $c 9-18: 1$ might have also interfered with biohydrogenation of other polyunsaturated fatty acids in the diet, resulting in the accumulation of $t$-18:1 (Mosley et al., 2002). Therefore, $t-18: 1$ isomers in milk are the result of incomplete biohydrogenation of unsaturated C18 fatty acids in the rumen (Shingfield and Griinari, 2007). Moreover, increment of these $t 10-18: 1$ spatial isomers has an important role in inhibition of de novo synthesis of short chain fatty acids and decrease in milk fat (Harvantine et al., 2009).

Feeding a blend of fish oil and an unsaturated fat source (Abughazaleh et al., 2002; Whitlock et al., 2002), and including high oleic and high linoleic sunflower seed with fish oil compared with a high stearic fat source (Abughazaleh et al., 2003), were more effective in increasing milk fat content of $c 9, t 11-18: 2$ than feeding them separately. However, Piperova et al. (2002) showed that approximately $93 \%$ of $c 9, t 11-18: 2$ appearing in milk fat is synthesized in the mammary gland from $t 18: 1$ via $\Delta^{9}$ desaturase, and Corl et al. (2001) reported that $\Delta^{9}$ desaturase activity is responsible for the yield of at least $65 \%$ of this isomer in milk fat. It has been reported that $c 9, t 11-18: 2$ isomer has health benefits associated with its consumption and the $t 10, c 12-18: 2$ isomer may be associated with decreased milk fat concentration and yield (Harvantine et al., 2009).

Milk fat of cows fed FO and FOCO diets had a higher level of 18:3 in comparison with control and $\mathrm{CO}$ diets. Similarly, the proportion of 18:3 increased when 14\% (DM) ground canola seed was included in the diet (Chichlowski et al., 2005). There were higher concentrations of EPA and DHA in FO and FOCO diets. Transfer of dietary fish oil fatty acids from diet to milk fat, specifically EPA and DHA, is generally low (AbuGhazaleh et al., 2002; Whitlock et al., 2002) because of their high biohydrogenation in the rumen and also because of their association with plasma lipoproteins, which are not good substrates for mammary lipoprotein lipase (Mansbridge and Blake, 1997). In general, including fish oil and canola oil, either separately or in combination, causes a decrease in short and medium chain fatty acids and an increase in long chain unsaturated fatty acids in milk fat, and the combination of fish oil and canola oil appears to result in an increase in beneficial long chain unsaturated fatty acids, including $c 9, t 11-18: 2$, in milk fat.

\section{CONCLUSION}

Results of the present study revealed that including fish oil in combination with canola oil would have less negative effect on DMI along with significant effects on milk fatty acid composition. Milk yield was not affected by including fish oil and canola oil in diets, but milk fat percentage and yield decreased on all supplemented diets. Supplementing the diet with fish oil and canola oil decreased short and medium chain fatty acids in milk fat and FO and FOCO diets produced a higher proportion of $t 10, c 12-18: 2$ and $c 9$, t11-18:2. The results from the current study show that including canola oil in combination with fish oil can effectively change fatty acid composition of milk fat.

\section{REFERENCES}

AbuGhazaleh, A. A., D. J. Schingoethe, A. R. Hippen and K. F. Kalscheur. 2004. Conjugated linoleic acid increases in milk when cows fed fish meal and extruded soybeans for an extended period of time. J. Dairy Sci. 87:1758-1766.

AbuGhazaleh, A. A., D. J. Schingoethe, A. R. Hippen and K. F. Kalscheur. 2003. Conjugated linoleic acid and vaccenic acid in rumen, plasma, and milk of cows fed fish oil and fats differing in saturation of 18 carbon fatty acids. J. Dairy Sci. 86:36483660 .

AbuGhazaleh, A. A., D. J. Schingoethe, A. R. Hippen and K. F. Kalscheur. 2003. Milk conjugated linoleic acid response to fish oil supplementation of diets differing in fatty acid profiles. J. Dairy Sci. 86:944-953.

AbuGhazaleh, A. A., D. J. Schingoethe, A. R. Hippen and L. A. Whitlock. 2002. Feeding fish meal and extruded soybeans enhances the conjugated linoleic acid (CLA) content of milk. J. Dairy Sci. 85:624-631.

AbuGhazaleh, A. A., D. J. Schingoethe, A. R. Hippen, K. F. Kalscheur and L. A. Whitlock. 2002. Fatty acid profiles of milk and rumen digesta from cows fed fish oil, extruded soybeans or their blend. J. Dairy Sci. 85:2266-2276.

Ashes, J. R., B. D. Siebert, S. K. Gulati, A. Z. Cuthbertson and T. W. Scott. 1992. Incorporation of n-3 fatty acids of fish oil into tissue and serum lipids of ruminants. Lipids 27:629-631.

Bayourthe, C., F. Enjalbert and R. Moncoulon. 2000. Effects of different forms of canola oil fatty acids plus canola meal on milk composition and physical properties of butter. J. Dairy Sci. 83:690-696.

Benson, J. A. and C. K. Reynolds. 2001. Effects of abomasal infusion of long-chain fatty acids on splanchnic metabolism of pancreatic and gut hormones in lactating dairy cows. J. Dairy Sci. 84:1488-1500.

Bauman, D. E. and J. M. Griinari. 2003. Nutritional regulation of milk fat synthesis. Annu. Rev. Nutr. 23:203-227.

Baumgard, L. H., J. K. Sangster and D. E. Bauman. 2001. Milk fat synthesis in dairy cows is progressively reduced by increasing supplemental amounts of trans-10, cis-12 conjugated linoleic acid (CLA). J. Nutr. 131:1764-1769.

Baumgard, L. H., B. A. Corl, D. A. Dwyer, A. Sæbø and D. E. 
Bauman. 2000. Identification of the conjugated linoleic acid isomer that inhibits milk fat synthesis. Anim. J. Physiol. 278:179-184.

Chang, J. H. P., D. K. Lunt and S. B. Smith. 1992. Fatty acid composition and fatty acid elongase and stearoyl-CoA desaturase activities in tissues of steers fed high oleate sunflower seed. J. Nutr. 122:2074-2080.

Chichlowski, M. W., J. W. Schroeder, C. S. Park, W. L. Keller and D. E. Schimek. 2005. Altering the fatty acids in milk fat by including canola seed in dairy cattle diets. J. Dairy Sci. 88:3084-3094.

Chilliard, Y. and A. Ferlay. 2004. Dietary lipids and forages interactions on cow and goat milk fatty acid composition and sensory properties. Reprod. Nutr. Dev. 44:467-492.

Chilliard, Y., A. Ferlay and M. Doreau. 2001. Effect of different types of forages, animal fat or marine oils in cow's diet on milk fat secretion and composition, especially conjugated linoleic acid (CLA) and polyunsaturated fatty acids. Livest. Prod. Sci. 70:31-48.

Corl, B. A., L. H. Baumgard, D. A. Dwyer, J. M. Griinari, B. S. Phillips and D. E. Bauman. 2001. The role of (9-desaturase in the yield of cis-9, trans-11 CLA. J. Nutr. Biochem. 12:622-630.

Cruz-Hernandez, C., J. K. G. Kramer, J. J. Kennelly, D. R. Glimm, B. M. Sorensen, E. K. Okine, L. A. Goonewardene and R. J. Weselake. 2007. Evaluating the conjugated linoleic acid and trans 18:1 isomers in milk fat of dairy cows fed increasing amounts of sunflower oil and a constant level of fish oil. J. Dairy Sci. 90:3786-380.

DePeters, E. J., J. B. German, S. J. Taylor, S. T. Essex and H. Perez-Monti. 2001. Fatty acid and triglyceride composition of milk fat from lactating Holstein cows in response to supplemental canola oil. J. Dairy Sci. 84:929-936.

Donovan, D. C., D. J. Schingoethe, R. J. Baer, J. Ryali, A. R. Hippen and S. T. Franklin. 2000. Influence of dietary fish oil on conjugated linoleic acid and other fatty acids in milk fat from lactating dairy cows. J. Dairy Sci. 83:2620-2628.

Griinari, J. M., B. A. Corl, S. H. Lacy, P. Y. Chouinard, K. V. Nurmela and D. E. Bauman. 2000. Conjugated linoleic acid is synthesized endogenously in lactating dairy cows by $\Delta^{9}$ desaturase. J. Nutr. 130:2285-2291.

Grummer, R. R. 1991. Effect of feed on the composition of milk fat. J. Dairy Sci. 74:3244-3257.

Harvatine, K. J., Y. R. Boisclair and D. E. Bauman. 2009. Recent advances in the regulation of milk fat synthesis. Animal 3:4054.

Harvatine, K. J. and M. S. Allen. 2006. Effects of fatty acid supplements on feed intake, and feeding and chewing behavior of lactating dairy cows. J. Dairy Sci. 89:1104-1112.

Ip, C., S. Banni, E. Angioni, G. Carta, J. McGruley, H. J. Thompson, D. Barbano and D. E. Bauman. 1999. Conjugated linoleic acid enriched butter fat alters morphogenesis and reduces cancer risk in rats. J. Nutr. 129:2135-2142.

Jenkins, T. C. 1998. Fatty acid composition of milk from Holstein cows fed oleamide or canola oil. J. Dairy Sci. 81:794-800.

Juchem, S. O., J. E. P. Santos, R. L. A. Cerri, R. C. Chebel, K. N. Galvaa, R. Bruno, E. J. DePeters, T. Scott, W. W. Thatcher and D. Luchini. 2008. Effect of calcium salts of fish and palm oils on lactational performance of Holstein cows. Anim. Feed Sci. Technol. 140:18-38.
Keady, T. W. J. and C. S. Mayne. 1999. The effects of level of fish oil inclusion in the diet on rumen digestion and fermentation parameters in cattle offered grass silage based diets. Anim. Feed Sci. Technol. 81:57-68.

Kelly, M. L., J. R. Berry, D. A. Dwyer, J. M. Griinari, P. Y. Chouinard, M. E. Van Amburgh and D. E. Bauman. 1998. Dietary fatty acid sources effect conjugated linoleic acid (CLA) concentrations in milk from lactating dairy cows. J. Nutr. 128:881-885.

Kepler, C. R., W. P. Tucker and S. B. Tove. Biohydrogenation of unsaturated fatty acids. IV. Substrate specificity and inhibition of linoleate -12-cis, -11-trans-isomerase from Butyrivibrio fibrisolvens. J. Biol. Chem. 245:3612-3620.

Lee, M. R. F., J. K. S. Tweed, A. P. Moloney and N. D. Scollan. 2005. The effects of fish oil supplementation on rumen metabolismand the biohydrogenation of unsaturated fatty acids in beef steers given diets containing sunflower oil. Anim. Sci. 80:361-367.

Lock, A. L. and K. J. Shingfield. 2004. Optimising milk composition. Dairying-Using Scince to Meet Consumers' Needs (Ed. E. Kebreab, J. Mills and D. E. Beever). Br. Soc. Anim. Sci. Nottingham University Press, Loughborough, United Kingdom. 29:107-188.

Mansbridge, R. J. and J. S. Blake. 1997. Nutritional factors affecting the fatty acids composition of bovine milk. Br. J. Nutr. 78(Suppl. 1):S37-S47.

Mosley, E. E., G. L. Powell, M. B. Riley and T. C. Jenkins. 2002. Microbial biohydrogenation of oleic acid to trans isomers in vitro. J. Lipid Res. 43:290-296.

Parodi, P. W. 1997. Cow's milk fat components as potential anticarcinogenic agents. J. Nutr. 127:1055-1060.

Palmquist, D. L. and J. M. Griinari. 2006. Milk fatty acid composition in response to reciprocal combinations of sunflower and fish oil in the diet. Anim. Feed Sci. Technol. 131:358-369.

Peterson, D. G., L. H. Baumgard and D. E. Bauman. 2002. Dosedependent reduction in milk fat secretion with abomasal infusion of trans-10, cis-12 conjugated linoleic acid (CLA) and comparison to diet-induced milk fat depression. J. Dairy Sci. 85(Suppl. 1):703.

Piperova, L. S., B. B. Teter, I. Bruckental, J. Sampugna, S. E. Mills, M. P. Yurawecz, J. Fritsche, K. Ku and R. A. Erdman. 2002. Mammary lipogenic enzyme activity, trans fatty acids and conjugated linoleic acids are altered in lactating dairy cows fed a milk fat-depressing diet. J. Nutr. 130:2568-2574.

Ramaswamy, N., R. J. Baer, D. J. Schingoethe, A. R. Hippen, K. M. Kasperson and A. Whitlock. 2001. Composition and flavor of milk and butter from cows fed fish oil, extruded soybeans, or their combination. J. Dairy Sci. 84:2144-2151.

SAS Institute. 1996. SAS/STAT: Changes and enhancements through release 6.11. SAS Inst. Inc., Cary, NC.

Shingfield, K. J. and J. M. Griinari. 2007. Role of biohydrogenation intermediates in milk fat depression. Eur. J. Lipid Sci. Technol. 109:799-816.

Shingfield, K. J., C. K. Reynolds, B. Lupoli, V. Toivonen, M. P. Yurawecz, P. Delmonte, J. M. Griinari, A. S. Grandison and D. E. Beever. 2005. Effect of forage type and proportion of concentrate in the diet on milk fatty acid composition in cows fed sunflower oil and fish oil. J. Anim. Sci. 80:225-238. 
Shingfield, K. J., S. Ahvenjs"rvi, V. Toivonen, A. A“ ro"la, K. V. V. Nurmela, P. Huhtanen and J. M. Griinari. 2003. Effect of fish oil on biohydrogenation of fatty acids and milk fatty acid content in cows. J. Anim. Sci. 77:165-179.

Ward, A. T., K. M. Wittenberg and R. Przybylski. 2002. Bovine milk fatty acid profiles produced by feeding diets containing solin, flax and canola. J. Dairy Sci. 85:1191-1196.
Whitlock, L., D. J. Schingoethe, A. R. Hippen, K. F. Kalscheur, R. J. Baer, N. Ramaswamy and K. M. Kasperson. 2002. Fish oil and extruded soybeans fed in combination increase CLA in milk of dairy cows more than when fed separately. J. Dairy Sci. 85:234-243.

Zheng, H. C., J. X. Liu, J. H. Yao, Q. Yuan, H. W. Ye, J. A. Ye and W. M. Wu. 2005. Effects of dietary sources of vegetable oils on performance of high-yielding lactating cows and conjugated linoleic acids in milk. J. Dairy Sci. 88:2037-2042. 